\title{
ФОТОИНИЦИИРОВАННОЕ СООКИСЛЕНИЕ БЕНЗ(а)ПИРЕНА С $n$-БЕНЗОХИНОНОМ И ПИРОКАТЕХИНОМ
}
I. SEVTSUK. BENSO(a)POREENI, $p$-BENSOKINOONI JA POROKATEHHIINI FOTOINITSIEERITUD KOOSOKSODEERIMINE

I. SHEVCHUK. PHOTOINDUCED CO-OXIDATION OF BENZO(A)PYRENE WITH $p$-BENZOQUINONE AND CATECHOL

\section{Представлена М. Губерерицем}

Ранее установлено взаимное влияние двух классов биологически активных соединений - фенолов и полициклических ароматических углеводородов (ПАУ) - на процессы фотоинициированного окисления [ $\left.{ }^{1}\right]$. Промежуточными продуктами окисления фенола, простейшего из членов гомологического ряда, принято считать пирокатехин; в их числе идентифицирован также $n$-бензохинон [ $\left.{ }^{2}\right]$.

В настоящей работе изложены результаты изучения кинетики раздельного и совместного окисления типичного представителя канцерогенного ПАУ -.

Таблица 1

Влияние $n$-бензохинона и пирокатехина на относительную скорость фотоинициированного окисления БП

\begin{tabular}{|c|c|c|}
\hline \multirow{2}{*}{ 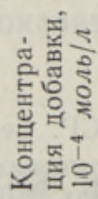 } & \multicolumn{2}{|c|}{$v_{\text {БП+добавка }} / v_{\text {БП }}$} \\
\hline & $\begin{array}{c}n \text {-Бензо- } \\
\text { хинон }\end{array}$ & $\begin{array}{l}\text { Пирока- } \\
\text { техин ** }\end{array}$ \\
\hline
\end{tabular}

\begin{tabular}{lll}
0,5 & 1,19 & $\overline{-}$ \\
1 & 1,44 & 1,06 \\
2 & 1,96 & $-\overline{-}$ \\
3 & - & 0,94 \\
5 & 2,57 & 0,95 \\
7,5 & - & 1,08 \\
10 & - & 0,90 \\
\hline
\end{tabular}

\footnotetext{
* Концентрация БП $1 \cdot 10^{-4}$ моль $/ \Omega$, скорость окисления $1,02 \cdot 10^{-5}$ моль $/ \Omega \cdot{ }^{2}$. ** Концентрация моль/л, скорость $2,34 \cdot 10^{-5}, \operatorname{Moлb} / \Omega \cdot 4$.
} бенз (а) пирена (БП) - в бинарных смесях с пирокатехином или с $n$-бензохиноном, инициированного полихроматическим излучением ртутной лампы сверхвысокого давления СВД-120 в диапазоне выше 200210 нм и с максимумом испускания при 365 нм [3]. Эксперимент проведен с растворами БП в 96\%-ном водном этаноле (концентрация БП $1 \cdot 10^{-4}$ моль/л и $5 \cdot 10^{-4}$ моль/л, температура $20 \pm 1^{\circ} \mathrm{C}$, при доступе кислорода и варьировании концентрации второго компонента в пределах, указанных в табл. 1). Использовались чистый БП фирмы «Fluka AG» (Швейцария); пирокатехин и $n$-бензохинон х. ч., дополнительно очищенные сублимацией. Содержание в растворе БП определялось спектрофотометрически по поглощению при 385 нм с учетом фона, содержание пирокатехина [ $\left.{ }^{4}\right]$ и $n$-бензохинона [5] - колориметрически по реакции с 4-аминоантипирином. Во всех случаях снижение концентрации основного вещества протекает линейно до его $40 \%$ конверсии, и кинетическим показателем реакции служит ее начальная скорость, 
Скорость фотоинициированного раздельного окисления $n$-бензохинона (Бх) и в присутствии БП (көнцентрация БП $1 \cdot 10^{-4}$ моль/л)

\begin{tabular}{|c|c|c|c|}
\hline 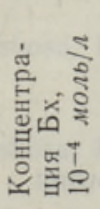 & 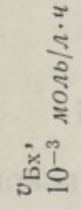 & 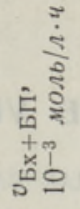 & 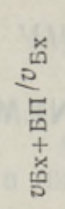 \\
\hline $\begin{array}{l}0,5 \\
1 \\
2 \\
5\end{array}$ & $\begin{array}{l}0,97 \\
1,86 \\
2,99 \\
5,39\end{array}$ & $\begin{array}{l}0,37 \\
0,75 \\
1,37 \\
3,15\end{array}$ & $\begin{array}{l}0,38 \\
0,40 \\
0,46 \\
0,58\end{array}$ \\
\hline
\end{tabular}

Скорость фотоинициированного раздельного окисления пирокатехина (П) и в присутствии БП (концентрация БП $5 \cdot 10^{-4}$ моль/л)

\begin{tabular}{|c|c|c|c|}
\hline 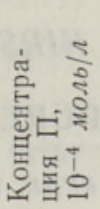 & 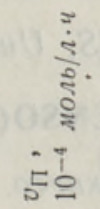 & 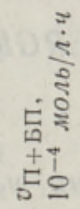 & $\begin{array}{l}\text { D } \\
\text { E } \\
\text { E } \\
\text { 咅 } \\
+\end{array}$ \\
\hline $\begin{array}{c}3 \\
5 \\
7,5 \\
10\end{array}$ & $\begin{array}{l}4,31 \\
5,80 \\
7,10 \\
7,80\end{array}$ & $\begin{array}{l}0,82 \\
1,04 \\
1,44 \\
1,83\end{array}$ & $\begin{array}{l}0,19 \\
0,18 \\
0,20 \\
0,23\end{array}$ \\
\hline
\end{tabular}

Добавка $n$-бензохинона и пирокатехина к БП (табл. 1) оказывает различное действие на его деградацию: первый из них ощутимо увеличивает, а второй практически не изменяет скорость превращения БП. Напомним, что, по данным ['], наличие собственно фенола в эквимолярной смеси с БП при концентрации его $1 \cdot 10^{-4}$ моль/ $\Omega$ способствует ускорению фотоокисления этого ПАУ в 1,7 раза. Следует учесть, что скорость окисления $n$-бензохинона (табл. 2) в присутствии БП на два порядка превышает скорость как раздельного, так и совместного с ним окисления БП. Следовательно, на ускоряющее действие $n$-бензохинона влияют продукты его окисления. Окисление $n$-бензохинона и пирокатехина ингибируется БП (табл. 2, 3).

Таким образом, можно полагать, что сенсибилизирующее влияние фенола при окислении БП объясняется ускоряющим действием самого фенола и продуктов его окисления.

\section{Л ИТ Р Р А Т У Р А}

1. К а р у Т., К и рсо У., Г убе рг риц М. Кинетика фотоинициированного соокисления бенз (а)пирена и фенолов разного строения. - Изв. АН ЭССР. Хим. Геол., 1973 , т. 22 , № 3, с. $217-223$.

2. Каплан В. Т., Перельштейн Е. И., Фесенко Н. Т. О механизмах самоочищения поверхностных вод суши от фенольных соединений. Сообщ. 1. Окисление простейшего фенола (карболовой кислоты) кислородом воздуха. - Гидрохим. материалы, 1966 , т. 42 , с. $274-286$.

3. Агросник Л. С. Сравнение яркостей некоторых источников для ультрафиолетовой микроскопин. - Биофизика, 1957, т. 2, вып. 4, с. $518-519$.

4. Ки р со У. Определение различных фенолов реакцией с 4-аминоантипирином. Изв. АН ЭССР. Хим. Геол., 1977, т. 26, № 1, с. $22-27$.

5. Thielem a n n, H. Zum Nachweis von p-Benzochinon mit 1-Phenyl-2,3-dimethyl-4aminopyrazolon-(5). - Pharmazie, 1969, Bd. 24, N 8, S. $483-484$.

Ннститут химии Академии наук Эстонской ССР
Поступила в редакцию $18 / \mathrm{I} 1979$ 